\title{
Preliminary investigation of a major high-strain zone in the Caledonian Highlands, southern New Brunswick
}

\author{
Adrian F. Park ${ }^{1 \dagger}$, Sandra M. Barr ${ }^{2}$ and Chris E. White ${ }^{3}$ \\ 1. Department of Geology, University of New Brunswick, PO Box 4400, Fredericton, New Brunswick E3B 5A3, Canada \\ 2. Department of Earth and Environmental Science, Acadia University, Wolfville, Nova Scotia B4P 2R6, Canada \\ 3. Department of Natural Resources, PO Box 698, Halifax, Nova Scotia B3J 2T9, Canada \\ †Corresponding author:<apark@unb.ca>
}

Date received:30July 2008 g Date accepted:24 October 2008

\begin{abstract}
A major ductile high-strain zone up to $5 \mathrm{~km}$ in width can be traced for at least $70 \mathrm{~km}$ diagonally across the Avalonian Caledonia terrane of southern New Brunswick. A study of the northeastern part of this zone from the Prosser Mountain area in the northwest to the Point Wolfe River area west of Fundy National Park shows that both the ca. 630-620 Ma Broad River Group and associated plutons and the 560-550 Ma Coldbrook Group contain similar structural elements, related to a largely shared deformational history. Some of this history is apparent also in the 560-550 Ma plutonic rocks. A pervasive foliation $\left(S_{1}\right)$ lies parallel to bedding $\left(S_{0}\right)$, and although evidently composite $\left(S_{0-1}\right)$ in the Broad River Group, this fabric is very heterogeneous in the younger Coldbrook Group, where low strain enclaves are widespread. No folds have been seen of an $F_{1}$ generation, and no reversals of facing or vergence are apparent. A mineral lineation $\left(\mathrm{L}_{\mathrm{m}}^{1}\right)$ is locally prominent, defined by biotite aggregates. The plutonic rocks have fabrics that developed during and soon after crystallization, including a foliation $\left(\mathrm{S}_{1}\right)$ producing augen-gneiss with a prominent L-tectonite $\left(\mathrm{L}_{\mathrm{m}}^{1}\right) . \mathrm{S}_{1}$ in the plutonic rocks also includes a schistosity associated with the growth of white mica and breakdown of feldspar. Geometry suggests that $S_{1}$ in the granites is related to $S_{0-1}$ in the supracrustal rocks, and the mineral lineation $\left(\mathrm{L}_{\mathrm{m}}^{1}\right)$ in both units shares a common orientation. $S_{1}$ and $S_{0-1}$ are crenulated by a strong second cleavage $\left(S_{2}\right)$ axial planar to folds $\left(\mathrm{F}_{2}\right)$, the large-scale expression of which is an asymmetric synform containing a belt of Coldbrook Group rocks. Kinematic indicators for $\mathrm{F}_{2}$ structures suggest an overall top-to-the-southeast motion along thrusts that stack units of Broad River Group, Coldbrook Group, and plutonic rocks. Fabric development in the older plutonic rocks implies a history of exhumation beginning under hot, anhydrous conditions during and soon after crystallization at ca. 620 $\mathrm{Ma}$, followed by hydration during retrogression as plutonic rocks were tectonically emplaced into this crustal stack. The age of the later tectonic events is not yet well constrained, but could be as late as Carboniferous.
\end{abstract}

\section{RÉSUMÉ}

Il est possible de retracer une importante zone de forte contrainte ductile ayant jusqu'à cinq kilomètres de largeur sur une distance de 70 kilomètres en diagonale à travers le terrane avalonien de Caledonia, dans le Sud du Nouveau-Brunswick. Une étude de la partie nord-est de cette zone à partir du secteur du mont Prosser, dans le nord-ouest, jusqu'au secteur de la rivière Pointe Wolfe, à l'ouest du parc national du Canada Fundy, révèle que le groupe d'environ 630 à $620 \mathrm{Ma}$ de la rivière Broad, les plutons connexes et le groupe de 560 à $550 \mathrm{Ma}$ de Coldbrook abritent des éléments structuraux similaires, apparentés à des déformations passées largement partagées. Une certaine partie de ce passé est également apparente dans les roches plutoniques de 560 à $550 \mathrm{Ma}$. Une foliation intense $\left(\mathrm{S}_{1}\right) \mathrm{se}$ manifeste parallèlement à la stratification $\left(S_{0}\right)$ et, même si cette fabrique est nettement composite $\left(S_{0-1}\right)$ dans le groupe de la rivière Broad, elle est très hétérogène dans le groupe plus récent de Coldbrook, où les enclaves de faible contrainte sont répandues. On n'a observé aucun pli d'une production $\mathrm{F}_{1}$ et aucune inversion du regard ni de la vergence n'est apparente. Une linéation minérale $\left(\mathrm{L}_{\mathrm{m}}^{1}\right)$, définie par des agrégats de biotite, est localement bien visible. Les roches plutoniques possèdent des fabriques qui se sont constituées pendant et peu après la cristallisation, notamment une foliation $\left(\mathrm{S}_{1}\right)$ produisant du gneiss oeillé avec L-tectonite $\left(\mathrm{L}_{\mathrm{m}}{ }_{\mathrm{m}}\right)$ en évidence. $\mathrm{S}_{1}$ à l'intérieur des roches plutoniques comporte en outre une schistosité associée à la croissance de mica blanc et à la décomposition de feldspath. La géométrie permet de supposer que $\mathrm{S}_{1}$ dans les granites est apparentée à $\mathrm{S}_{0-1}$ dans les roches supracrustales et que la linéation minérale $\left(\mathrm{L}_{\mathrm{m}}{ }_{\mathrm{m}}\right)$ dans les deux unités partage une orientation commune. $\mathrm{S}_{1}$ et $\mathrm{S}_{0-1}$ sont crénelés par une seconde schistosité $\left(\mathrm{S}_{2}\right)$ prononcée, de plan axial par rapport aux plis $\left(\mathrm{F}_{2}\right)$, dont l'expression à grande échelle est une synforme asymétrique renfermant une ceinture de roches du groupe de Coldbrook. Les indicateurs cinématiques des structures $\mathrm{F}_{2}$ permettent de supposer un mouvement général du sommet vers le sud-est le long des chevauchements qui empilent les unités du groupe de la rivière Broad, du groupe de Coldbrook et des roches plutoniques. Le développement de la fabrique dans 
les roches plutoniques plus âgées suppose une exhumation passée ayant commencé dans des conditions très chaudes et anhydres pendant et peu après la cristallisation, vers $620 \mathrm{Ma}$, suivie par une hydratation pendant la rétrogression au moment où les roches plutoniques se sont tectoniquement mises en place à l'intérieur de cet éperon crustal. L'âge des événements tectoniques tardifs n'est pas encore bien circonscrit, mais ils pourraient remonter au Carbonifère.

\section{[Traduit par la redaction]}

\section{INTRODUCTION}

The Caledonian Highlands of southern New Brunswick consist mainly of Late Neoproterozoic volcanic, sedimentary, and plutonic rocks and overlying Cambrian to early Ordovician sedimentary rocks, known collectively as the Caledonia terrane (Barr and White 1996, 1999). The Caledonia terrane is part of Avalonia, a composite peri-Gondwanan terrane containing segments generally recording Neoproterozoic to Cambrian histories of deposition, igneous activity, and deformation (e.g., Hibbard et al. 2006). Following on earlier mapping by Ruitenberg et al. $(1975,1979)$, the Caledonia terrane was mapped at 1:10 000 scale during the 1980s and early 1990s, and published in 1:50 000 scale compilations (e.g., Barr and White 1988, 1993, 1999; McLeod 1987). Revised maps based on the same field work combined with additional information from adjacent areas of younger rocks were published at 1:20 000 scale in 2004 (Barr and White 2004a and references thereon). These maps also established lithostratigraphic units at the formational level in the Neoproterozoic stratified sequences. Although structural features were noted on these maps and interpreted at a reconnaissance level in Barr and White (1999), the work was not concerned primarily with the deformational history of the area. Structural studies had also been done earlier as part of a regional reconnaissance (Ruitenberg et al. 1973, $1975,1979)$, but no more recent attempt has been made to elucidate deformation history and integrate it into stratigraphic and intrusive histories, the focus of the present project. Such studies have implications throughout Avalonia, which is known to be characterized by a complex structural history linked in large part to strike-slip tectonics (e.g., Murphy et al. 2001; Murphy 2006).

This paper presents the results of a preliminary study of the northeastern part of a major ductile high-strain zone up to $5 \mathrm{~km}$ wide that cuts obliquely across the Caledonia terrane from the Prosser Brook area in the northeast to the coast near Big Salmon River in the southwest (Fig. 1, inset; Barr and White 2004b, 2004c, 2004d, 2004e, St. Peter et al. 2004). The zone contains enclaves of ca. 560-550 Ma Coldbrook Group bounded by ca. $620 \mathrm{Ma}$ Broad River Group and intrusions of the Point Wolfe River Plutonic Suite with modified unconformable and intrusive relationships (Fig. 1). This high-strain zone is one of a series of regional features that can be traced west at least as far as the Saint John area (Ruitenberg et al. 1973), and around Big Salmon River also incorporates tectonic enclaves of the Cambrian-Ordovician Saint John Group (McLeod and McCutcheon 1981; McLeod 1987).

\section{GEOLOGICAL BACKGROUND}

Barr and White (1988, 1993, 1999, 2004a) developed a stratigraphic subdivision of the supracrustal rocks of the Caledonia terrane, recognizing an older Broad River Group and younger Coldbrook Group. Contacts between the two units are now tectonic, but the original relationship is assumed to have been unconformable. Both groups were intruded by comagmatic plutonic rocks, including the Point Wolfe River Plutonic Suite and related intrusions emplaced into the Broad River Group below the unconformity, and a younger suite intruding both groups. U-Pb (zircon) dating has constrained the intrusive events at 630-615 Ma for the Point Wolfe River Plutonic Suite, and 560-550 Ma for the younger Bonnell Brook, Mechanic Settlement, and related intrusions (Bevier and Barr 1990; Barr et al. 1994; Barr and White 1999). U-Pb (zircon) dating of volcanic components of the Broad River and Coldbrook groups, as well as their petrochemical similarities to the plutonic units of corresponding ages, indicate that the Broad River and Coldbrook groups have ages of ca. 630-620 $\mathrm{Ma}$ and 560-550 Ma, although the maximum age of the Broad River Group is not constrained (Barr and White 1999). Both the Broad River and Coldbrook groups have been subdivided into lithostratigraphic formations, and younging and facing information from the Coldbrook Group is reliable to the point where relative age relationships of these formations can be tentatively identified. Such relationships in the Broad River Group remain ambiguous as few reliable way-up and younging indicators have been found, mainly due to pervasive transposition into the first foliation $\left(\mathrm{S}_{0-1}\right)$. The Broad River Group and associated plutons formed in a continental margin magmatic arc setting, whereas the Coldbrook Group and associated plutons formed in a post-arc rifting environment (Barr and White 1999). The Hammondvale Metamorphic Suite, a faultbounded sliver on the northwestern edge of the Caledonia terrane (Fig. 1, inset), has been interpreted to be a accretionary complex on the trench side of the Broad River Group magmatic arc (White et al. 2001), indicating that subduction was to the southeast (present-day coordinates).

Those aspects of Caledonia terrane stratigraphy that are relevant to the high-strain zone which is the subject of this study are presented here; more regional details are provided by Barr and White (1999, 2004b, 2004c, 2004d, 2004e) and St. Peter et al. (2004). Three formations of the Broad River Group occur in the area (Fig. 1): Hayward Brook Formation (mafic and felsic tuff, amygdaloidal basalt, minor rhyolite, abundant pyrite-rich felsic layers, sheets of quartz-rich granitic rocks, and phyllitic metasedimentary and metatuffaceous rocks); Pine Brook Formation (metasiltstone, metasandstone, and metamor- 


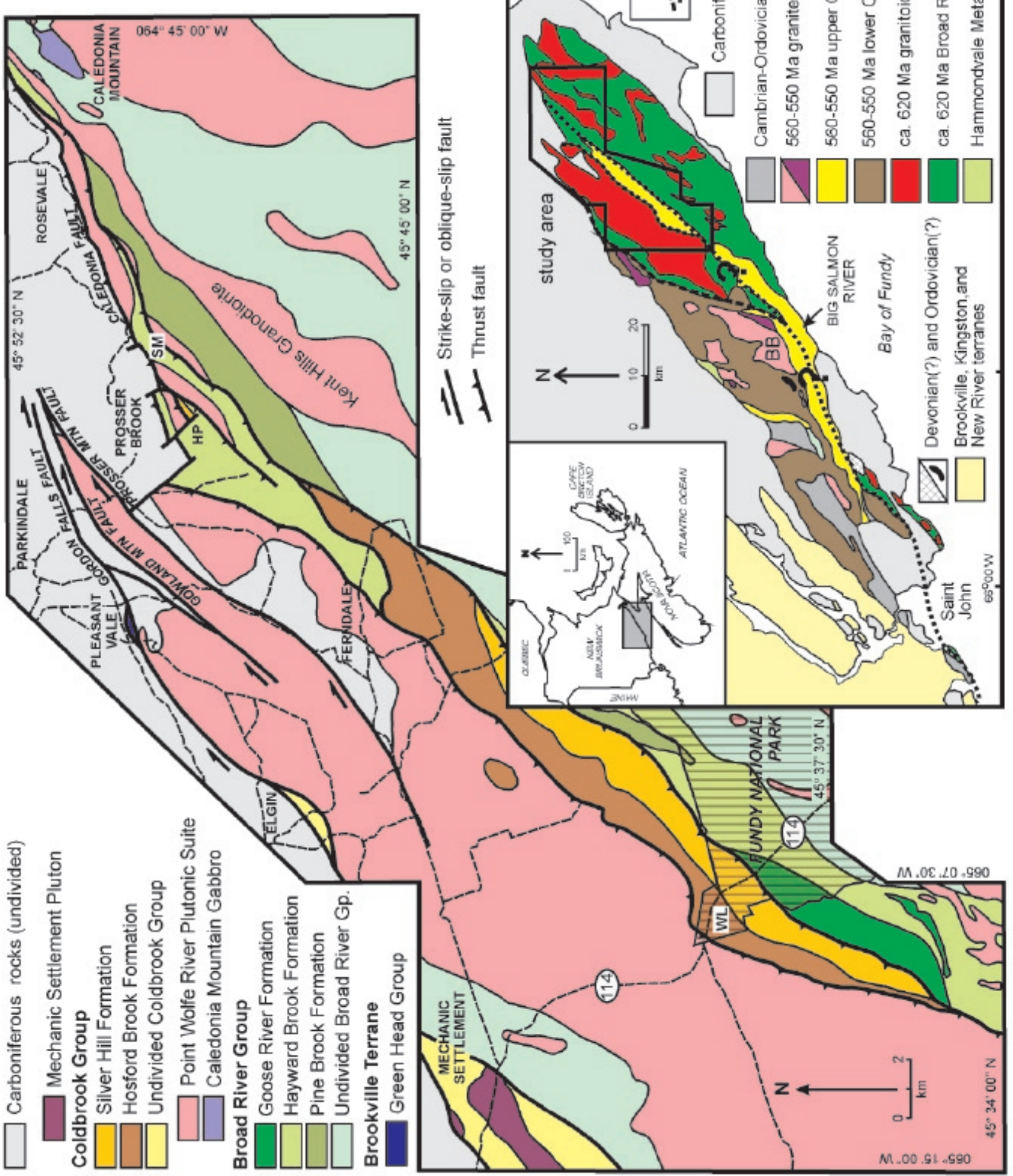

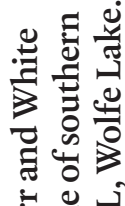

츨

可

党.

둔 음

歌

है

$3 \cdot 3$

艺重

定前

要

吾䓃

o

है

元的

호월

I

폴 훙

흥

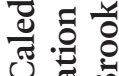

ن

으 $\overline{\mathrm{d}}$

फै है

声兵

:

$\Xi \ddot{g}$

‡ै $\dot{\bar{\delta}}$.

율.

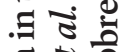

ฮ เ ว

च छ

원

这

ษั)

늉

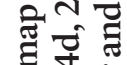

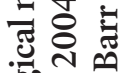

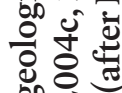

跑

守.

융

-

붕용

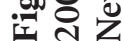


phosed pebble conglomerate, the last two units being notably arkosic); and Goose River Formation (red, maroon, and grey slate, phyllite, arkosic metasandstone, metaconglomerate, and minor micaceous metaquartzite). Stratigraphic relations among these units are uncertain, although Barr and White (1999) suggested that the Goose River Formation is youngest and Pine Brook oldest based on limited evidence of younging directions.

Two formations of the Coldbrook Group are represented in the study area: Silver Hill Formation (red to grey, commonly flow-banded rhyolite and rhyolitic tuff, locally with laminated siltstone and chert) and Hosford Brook Formation (amygdaloidal to massive basalt, with minor mafic tuff). The Silver Hill Formation consistently overlies the Hosford Brook Formation, and limited younging indicators suggest that this relationship is a primary depositional feature.

The distribution of these lithologies as shown by Barr and White (2004b, 2004c, 2004d, 2004e) and St. Peter et al. (2004) has been modified only slightly as a result of work during this study. A new area of Coldbrook Group has been defined around Hayward Pinnacle, consisting of metabasalt with an intrusion of porphyritic dacite or rhyolite forming the Pinnacle itself, south of Prosser Brook (Fig. 1). The basalt is considered to be part of the Hosford Brook Formation, whereas the dacite/ rhyolite dome may be linked to the Silver Hill Formation.

\section{STRUCTURAL ANALYSIS}

For the purposes of structural analysis the area covered by this project has been divided into four domains: west of Fundy National Park, north of Fundy National Park, Ferndale area, and south of Prosser Brook (an area including Hayward Pinnacle and Stuart Mountain; Fig. 2). These domains were selected on the basis of relatively good exposure, the presence of critical lithologies, and access sufficient to allow traverses through potential macro-scale fold structures based on the work of Barr and White (1999).

\section{Structures in the Broad River Group}

Rocks of the Broad River Group are dominated by a pervasive, penetrative foliation that is generally parallel to bedding $\left(\mathrm{S}_{0-1}\right)$. Locally, in meta-arkose of the Pine Brook and Goose River formations or the more massive felsic and mafic metavolcanic rocks of the Hayward Brook Formation, bedding and foliation are distinct (Figs. 3a-e), but no consistent vergence changes have been recorded. Two traverses, one west of Fundy National Park and another north of Fundy National Park, were chosen because they cross relatively well-exposed examples of outcrop patterns that are potential examples of folds associated with the $S_{0-1}$ foliation (Fig. 2). In both cases enclaves of Pine River Formation are surrounded with apparent closure by Hayward Brook Formation. No folds $\left(\mathrm{F}_{1}\right)$ associated with this foliation have been recorded at any scale in the area covered by this project, nor have any consistent changes in way-up been observed.
Where way-up criteria are preserved they suggest younging to the northwest or north-northwest, consistent with the observations and conclusions of earlier studies (e.g., Ruitenburg et al. 1979; Barr and White 1999).

The $S_{0-1}$ foliation is expressed by white mica or chlorite growth in felsic metavolcanic rocks, white mica beards on detrital feldspar and quartz grains in meta-arenite, and chlorite with rare green amphibole growth in metabasaltic lithologies. Mica beards in metasedimentary rocks and deformed pumice shards, lapilli, and less well-characterized fragments in metavolcanic rocks all define a pervasive stretching lineation $\left(\mathrm{L}_{\mathrm{m}}^{1}\right)$ within $\mathrm{S}_{0-1}$. The lineation typically lies close to the down-dip direction on the foliation $\left(\mathrm{S}_{0-1}\right)$ and therefore has consistent plunge to the northwest or north-northwest. Locally, later folding $\left(\mathrm{F}_{2}\right)$ has changed this orientation to a plunge to the southeast or south-southeast (Fig. 4).

Kinematic indicators within this early $S_{0-1}$ foliation consist of $S-C$ fabrics, porphyroclast wings ( $\sigma$ type), and deformed veinlets. The sense of these indicators is consistent with top-to-thesoutheast. At most locations the $S_{0-1}$ fabric does not show any asymmetry. Where markers exist, such as in the metavolcanic rocks of the Hayward Brook Formation (lithic clasts, pumice shards, etc.), they define a prolate ellipsoid close to the plane of $S_{0-1}$, but local exceptions occur. The most striking of these exceptions is seen in metaconglomerate of the Pine River Formation in the domain north of Fundy National Park (Fig. 2, Figs. 3f, g). The meta-arkosic matrix in this lithology displays a conspicuous $\mathrm{L}_{\mathrm{m}}^{1}$ lineation implying the typical prolate strain, but the cobble- and pebble-sized clasts of vein quartz, with aspect ratios around 1:2:2, are consistently oblate in the plane of the $S_{0-1}$ foliation (Fig. 3f, g). Other clast types, such as fine-grained carbonate, calc-silicate, red chert, and shale have higher aspect ratios, but still display oblate ellipsoids.

A second foliation $\left(\mathrm{S}_{2}\right)$ forms a widespread crenulation cleavage throughout outcrops of the Broad River Group (Fig. 5a, b). Its scale varies considerably, from a septal spacing around $1 \mathrm{~mm}$ and a comparable wavelength, to septal spacings as wide as 15 $\mathrm{mm}$, and a crenulation wavelength around $10 \mathrm{~mm}$. It is axial planar to open folds $\left(\mathrm{F}_{2}\right.$, Fig. $\left.5 \mathrm{a}, \mathrm{b}\right)$, asymmetry of which defines a broad synformal keel trending southwest through the main outcrop of Coldbrook Group from Ferndale to the southern part of the domain west of Fundy National Park (Fig. 2). The crenulation lineation $\left(\mathrm{L}_{2}\right)$, and $\mathrm{S}_{2}-\mathrm{S}_{0-1}$ intersection lineation $\left(\mathrm{L}_{2}{ }_{2}\right)$ are proxies for the $\mathrm{F}_{2}$ fold axes and generally plunge to the southwest or west with very local reversals to the northeast or east (Fig. 4, 5).

The $\mathrm{S}_{2}$ crenulation cleavage is defined by bending of mica and chlorite in the $S_{0-1}$ foliation, and this fabric is reinforced locally by new growth of chlorite and white mica in the $S_{2}$ septae.

\section{Structures in the Coldbrook Group}

Both generations of structural fabrics noted in the Broad River Group are also present in rocks of the Coldbrook Group; however, their development is far more heterogeneous (Fig. 


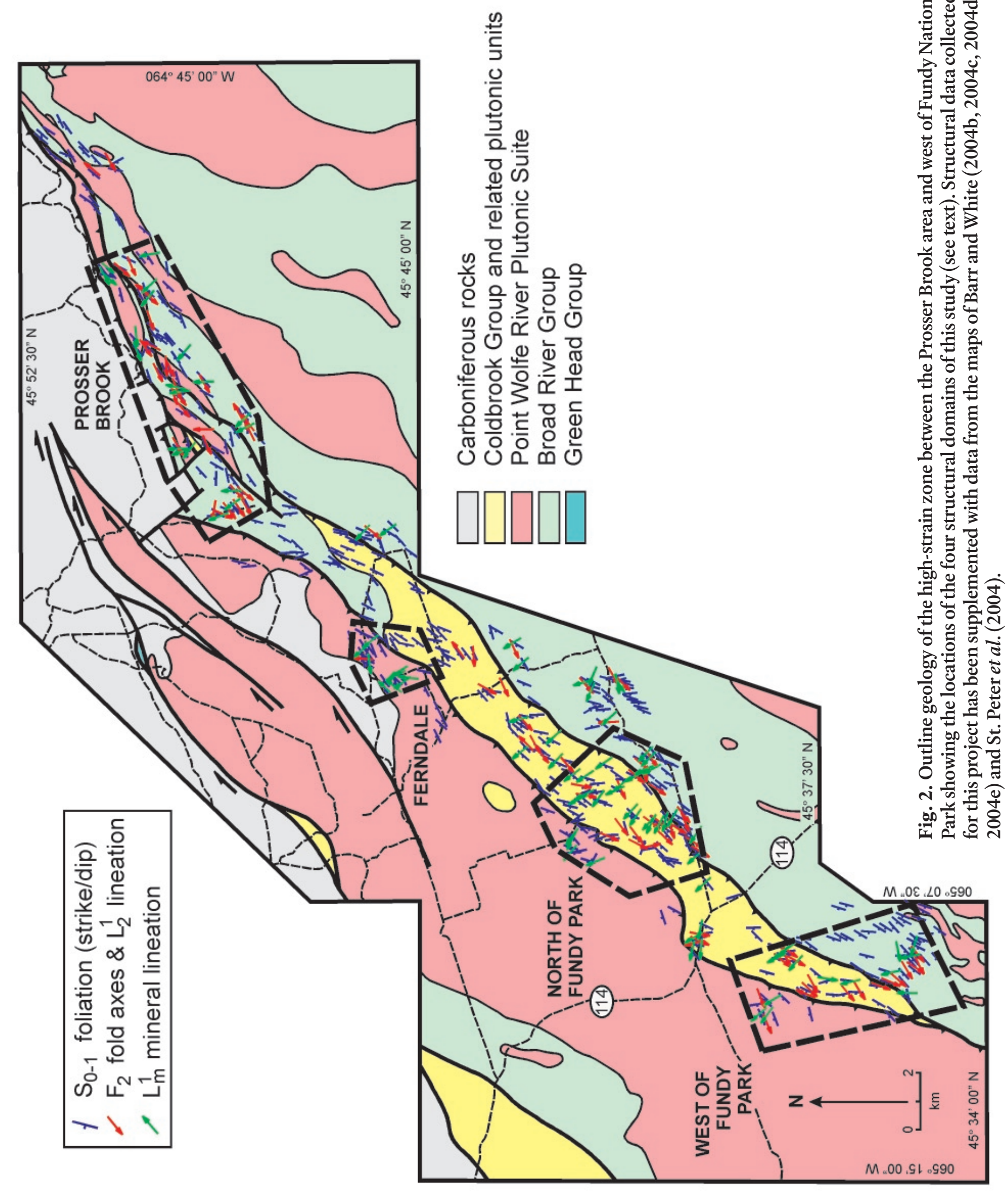



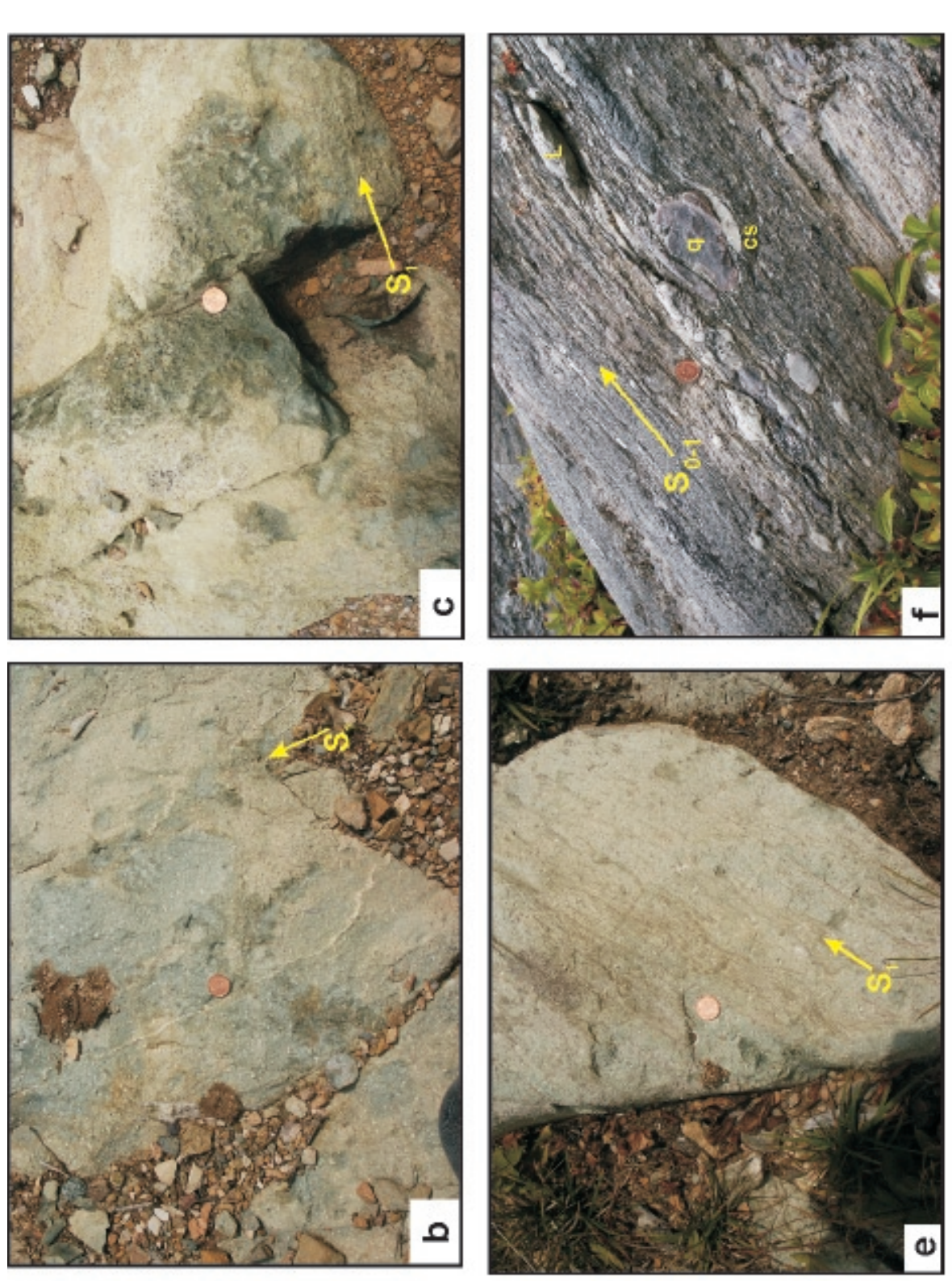

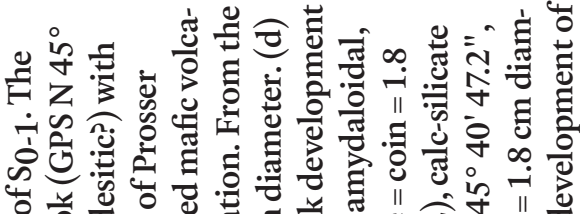

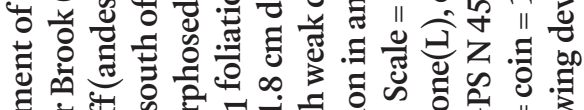

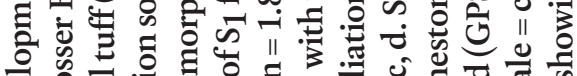

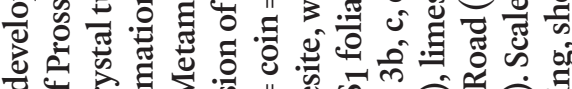
च फ

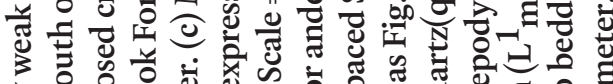
की

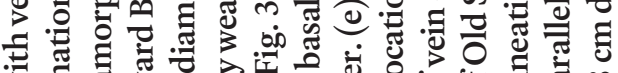

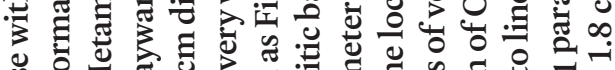

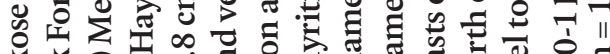

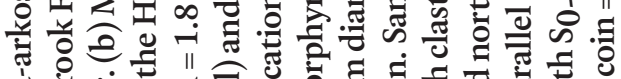

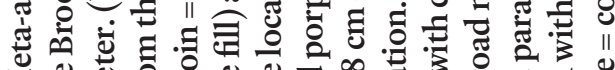
之. (ิ) 을 छ

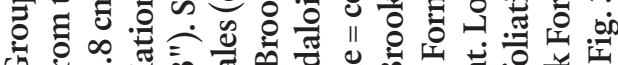

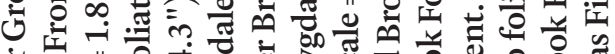

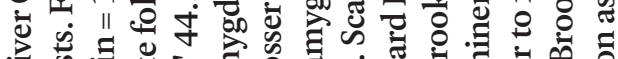

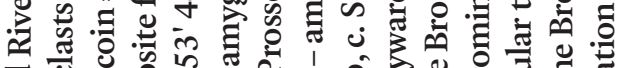
चु

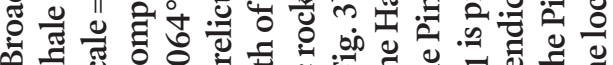
可 :

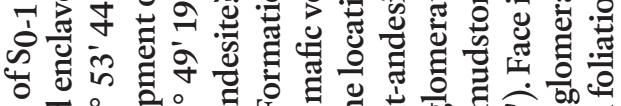
ชे

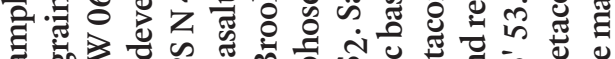
营

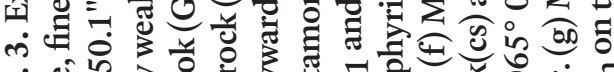

-
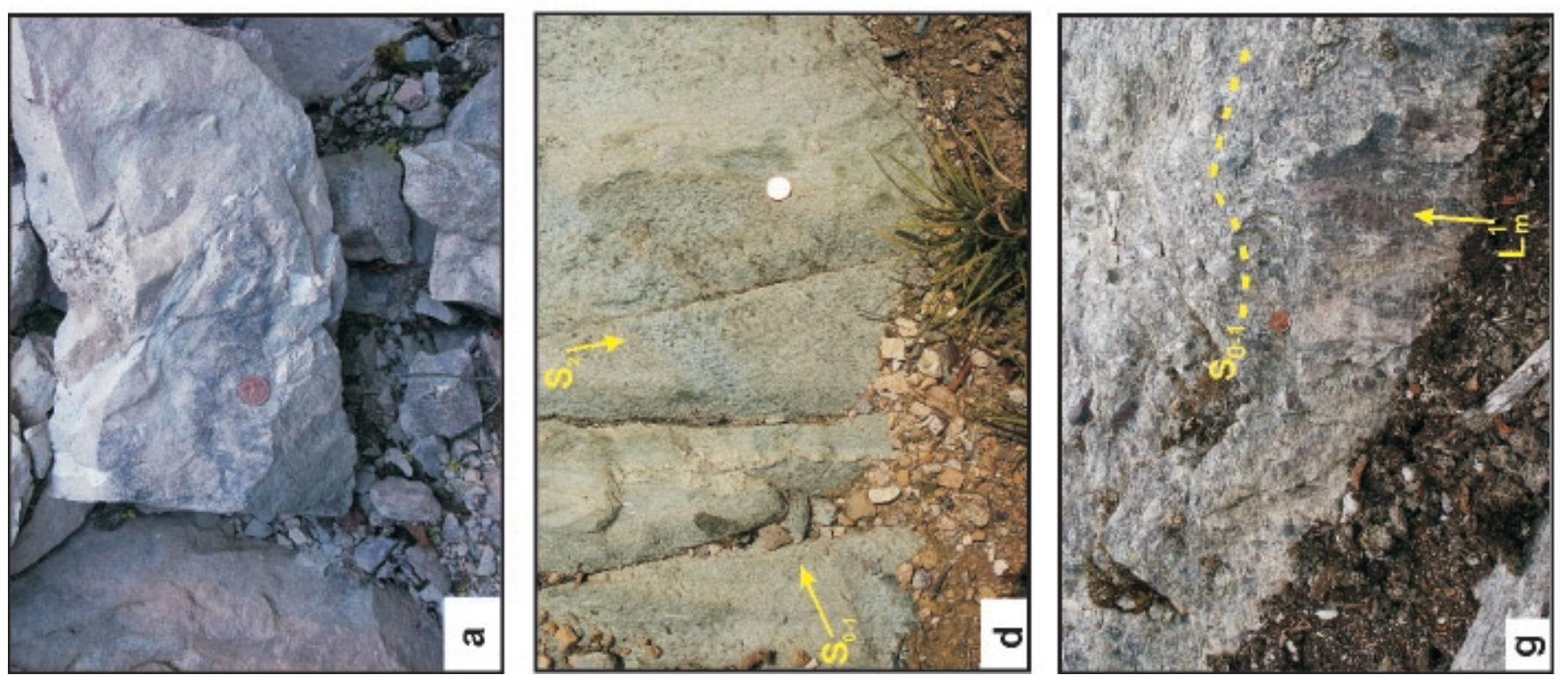


\section{West of Fundy National Park}

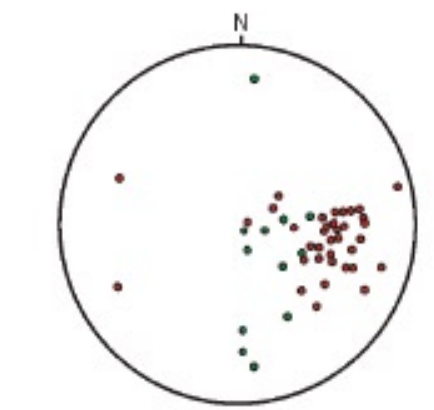

- poles to $S$, in granitoids $(n=12)$

- poles to $S_{i, 1}$ in supracrustal rocks $(n=37$ )

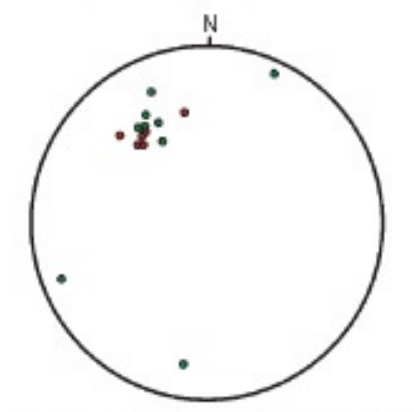

mineral lineation $\mathrm{L}^{+}$and $\mathrm{L}_{\mathrm{s}}(\mathrm{n}=15)$ - in granitoid rocks - in supracrustal rocks

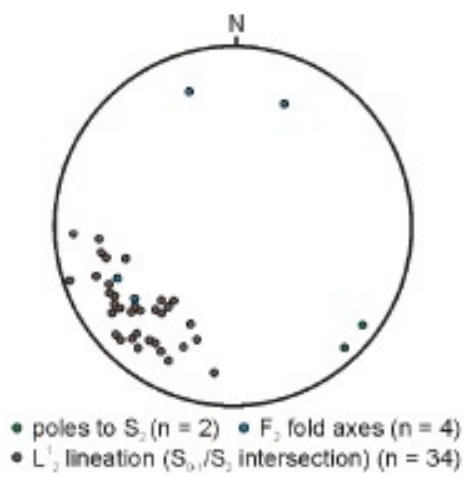

North of Fundy National Park

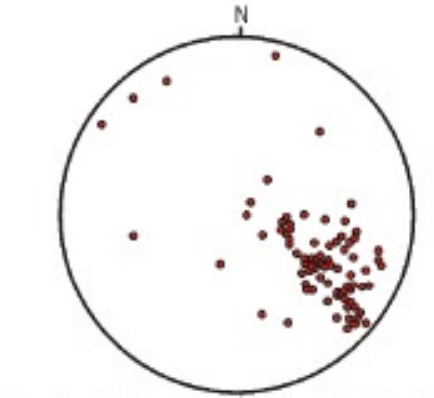

- poles to $\mathrm{S}_{0,} / \mathrm{S}_{1}$, supracrustal rocks $(\mathrm{n}=81)$
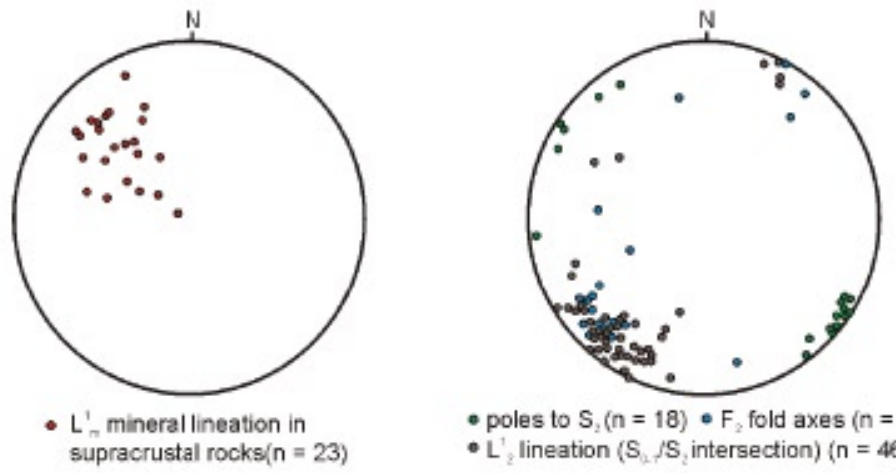

- poles to $S_{2}(n=18) \cdot F_{2}$ fold axes $(n=18)$ - $L^{\prime}$ lineation $(S, / S$, intersection) $(n=46)$

\section{South of Prosser Brook}

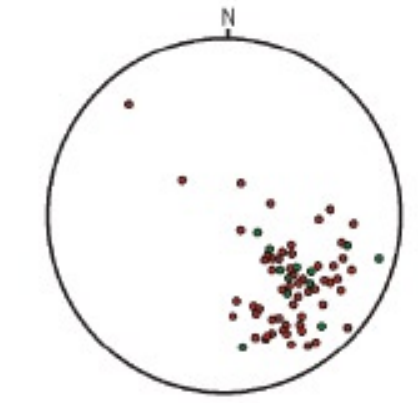

- poles to $S$, in granitoids $(n=12)$

- poles to $S_{0,}$ in supracrustal rocks $(n=59)$

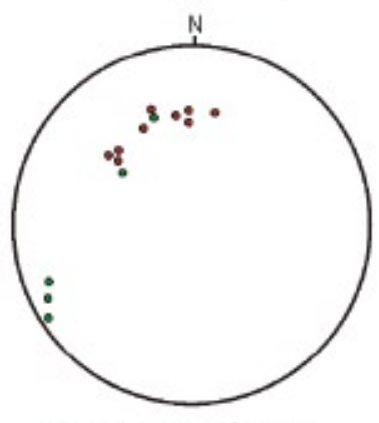

mineral lineation $\mathrm{L}^{\prime}$, and $\mathrm{L}_{\text {, }}$

- in granitoid rocks $(n=5)$

- in supracrustal rocks $(n=9)$

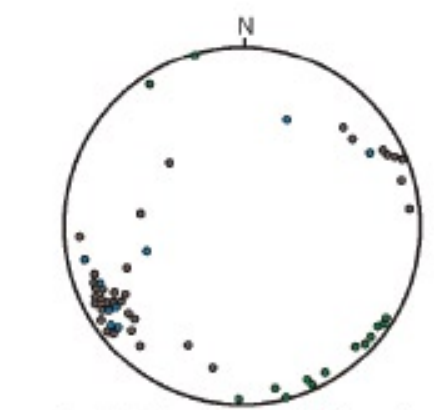

- poles to $S_{2}(n=14) \cdot F_{2}$ fold axes $(n=9)$ - $\mathrm{L}_{2}{ }_{2}$ lineation $\left(\mathrm{S}_{\mathrm{L}, 1} / \mathrm{S}\right.$ intersection) $(\mathrm{n}=35)$

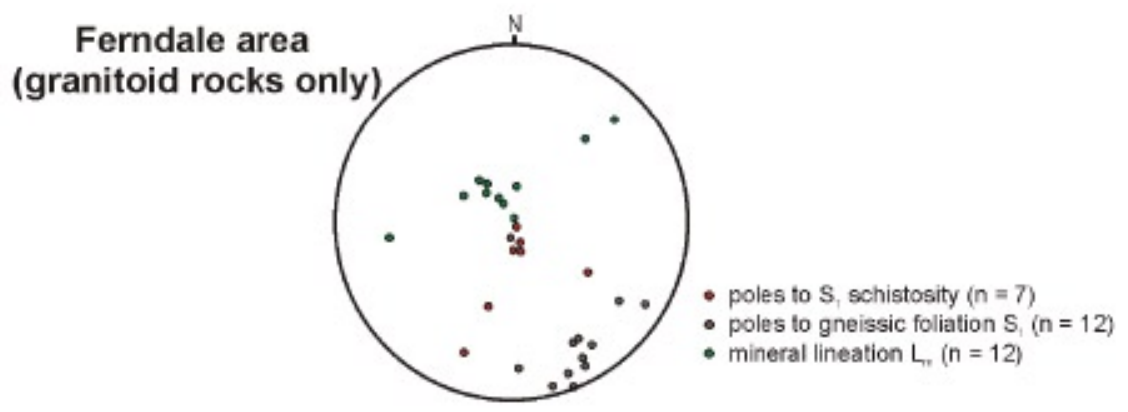

Fig. 4. Stereographic projections of structural elements in the four domains along the high- strain zone between the Prosser Brook area and west of Fundy National Park (see Fig. 2 for locations). All stereonets are equal-area lower hemisphere projections. 

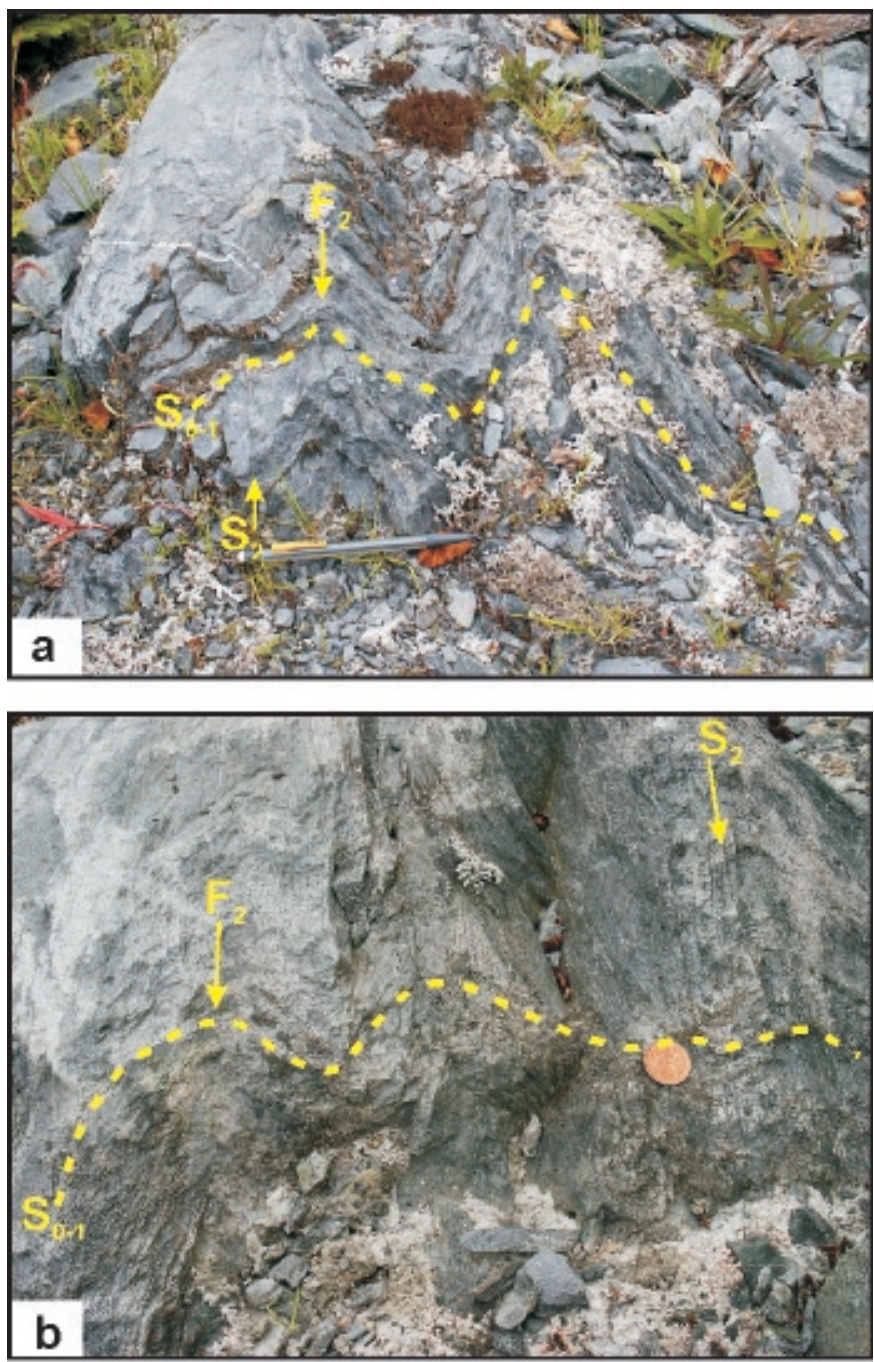

Fig. 5. (Above) Examples of $F_{2} / S_{2}$ in the Broad River Group. (a) Grey chloritic meta-arkose in the Pine Brook Formation with composite foliation $\mathrm{S}_{0-1}$ affected by $\mathrm{F}_{2}$ folds with $S_{2}$ axial planar crenulations cleavage. Logging road north of Old Shepody Road (GPS N $45^{\circ} 40^{\prime} 49.2^{\prime \prime}$, W $\left.065^{\circ} 03^{\prime} 54.3^{\prime \prime}\right)$. Scale $=$ pen $=15 \mathrm{~cm}$. (b) Grey chloritic meta-arkose (same location as Fig. 5a) with $\mathrm{F}_{2}$ folds affecting composite foliation $S_{0-1}$, with axial planar $S_{2}$ crenulation cleavage. Scale $=$ coin $=1.8 \mathrm{~cm}$ diameter.

Fig. 6. (Right) Examples of $S_{0-1}$ in the Coldbrook Group. (a) Banded and foliated metarhyolite from the Silver Hill Formation north of Old Shepody Road (GPS N 45 $41^{\prime}$ $\left.15.7^{\prime \prime}, \mathrm{W} 065^{\circ} 05^{\prime} 03.2^{\prime \prime}\right)$. Foliation parallel to primary banding $\left(\mathrm{S}_{0-1}\right)$ with $\mathrm{L}_{\mathrm{m}}^{1}$ lineation formed from flattened and elongate shards (possibly fiamme). Scale $=$ coin $=2.4$ $\mathrm{cm}$ diameter. (b) Foliated greenstone (metabasalt with epidote-calcite-quartz amygdales) with $S_{1}$ foliation, from the Hosford Brook Formation south of Old Shepody Road (GPS N 45 37' 24.7", W $\left.065^{\circ} 09^{\prime} 42.2^{\prime \prime}\right)$, Scale = coin $=1.8$ $\mathrm{cm}$. (c) Deformed and schistose metarhyolite with de-
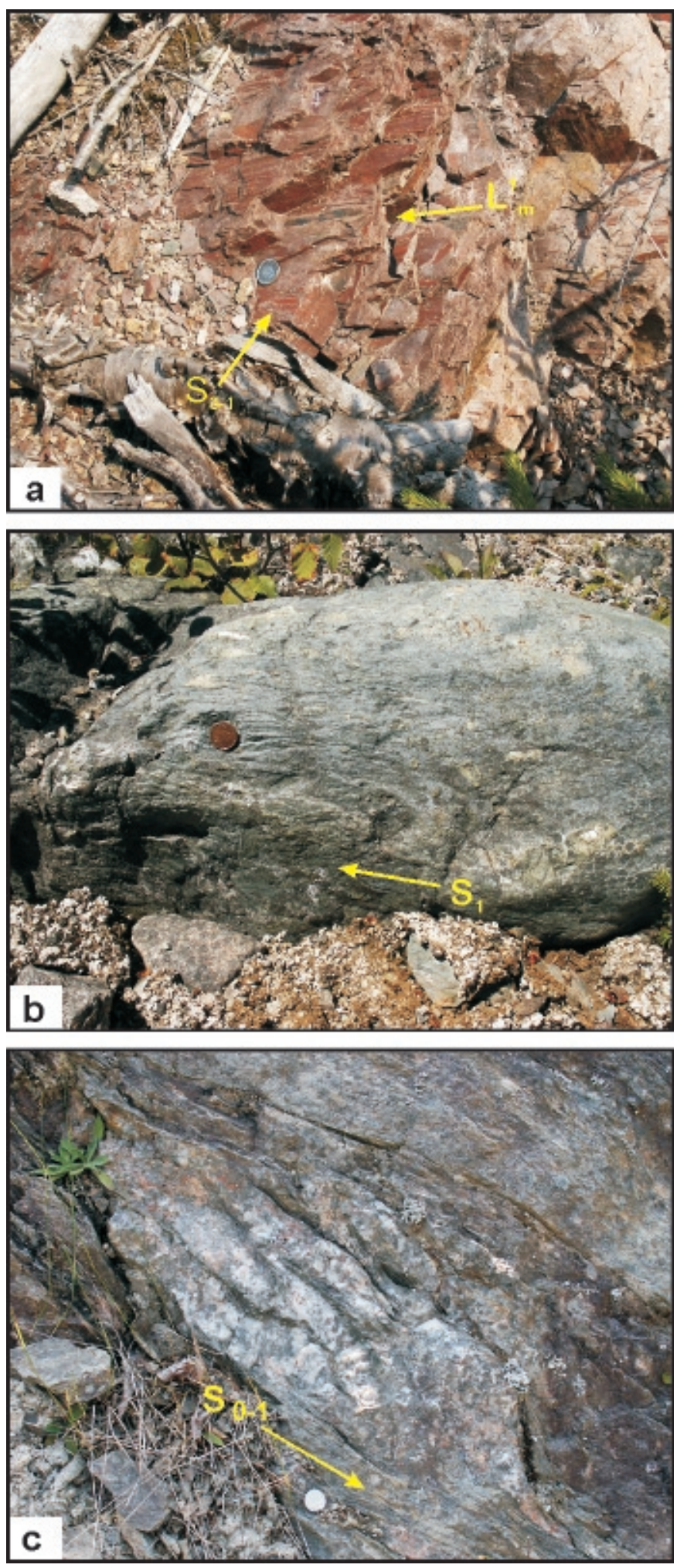

formed quartz veins, Hosford Brook Formation, displaying a C-S fabric. Movement sense is top-to-the-left (in this view, south). Vertical face on road cut west side of Highway 114 (GPS N $45^{\circ} 39^{\prime} 37.7^{\prime \prime}$, W $\left.065^{\circ} 08^{\prime} 03.7^{\prime \prime}\right)$. Scale = coin = $2.4 \mathrm{~cm}$ diameter. 
$6 a-c)$. The early $S_{0-1}$ foliation is generally bedding-parallel, as in the rocks of the Broad River Group, but in the more massive rhyolitic and basaltic lithologies it may be weak or absent (Fig. $6 \mathrm{a}, \mathrm{b})$. Shards and clasts show the same development of mica beards, or prolate extension as $\mathrm{L}_{\mathrm{m}}^{1}$ close to the plane of $\mathrm{S}_{0-1}$, but this phenomenon is also restricted to those rocks where the foliation is strong, such as the banded rhyolite/welded tuff (Fig. 6a) exposed north of Fundy National Park (around GPS location N 45 41' 15.7" W $065^{\circ} 05^{\prime} 03.2^{\prime \prime}$ ) and in the road-cuts along Highway 114 near the Park entrance at Wolfe Lake (GPS location N 45 39' 37.7" W $065^{\circ} 08^{\prime} 03.7^{\prime \prime}$ ). In both cases unfoliated porphyritic metarhyolite is interfingered with S-L tectonite, illustrating the extremely heterogeneous nature of the Coldbrook Group. Likewise, some of the basalt in the domains north and west of Fundy National Park is massive, non-foliated, and amygdaloidal, interfingered with strongly foliated metabasalt, where the epidote-filled amygdales are distinctly prolate or oblate (Fig. 6b)

Occurrence of $\mathrm{F}_{2}$ minor folds and the $\mathrm{S}_{2}$ crenulation cleavage in the Coldbrook Group rocks is strongly dependent on the degree of anisotropy induced by the heterogeneous $S_{0-1}$ foliation. In the least foliated lithologies, $S_{2}$ is represented by consistently orientated near-vertical fractures spaced greater than $2 \mathrm{~cm}$ apart (Fig. 7a). In the well-foliated lithologies a finer crenulation cleavage (spacing of septae $<1 \mathrm{~mm}$ ) is seen.

Asymmetry of $\mathrm{F}_{2}$ minor folds, the $\mathrm{L}_{2}{ }_{2}$ intersection lineation, and the plunge and trend of the $\mathrm{L}_{2}$ crenulation lineation (Fig. $7 \mathrm{~b}$ ) along the length of the main outcrop of the Coldbrook Group define the closure of a broad $\mathrm{F}_{2}$ synform between Ferndale in the northeast and the southern end of the domain west of Fundy National Park; however, based on the map pattern, this structure has an overall asymmetry (Fig. 2, 4). Only in the domain north of Fundy National Park can both limbs be clearly seen: elsewhere the northern limb is cut out against the outcrop of the Point Wolfe River Plutonic Suite. Kinematic indicators in the $\mathrm{S}_{0-1}$ foliation (veins, porphyroclasts, and S-C fabrics; Fig. 6c) consistently indicate top-to-the-southeast, although the data are from mainly the southern limb of the synform. Way-up indicators demonstrate that the $\mathrm{F}_{2}$ synform is a syncline in the Coldbrook Group.

Exposure is very limited along the northern limb of this $\mathrm{F}_{2}$ structure; however, in an area north of Fundy National Park, it is adequate to reveal structural complications. Firstly, mafic rocks of the underlying Hosford Brook Formation dip away from felsic rocks of the Silver Hill Formation, implying that the succession is reversed (e.g. around GPS location N 45 41' 15.7", W $065^{\circ} 05^{\prime} 03.2$ "). Secondly, enclaves of foliated quartz diorite of the Point Wolfe River Plutonic Suite (pre-Coldbrook Group plutons intruded into the underlying Broad River Group) occur along the boundary between the Hosford Brook and Silver Hill formations; the best example is along a logging road at GPS location N $45^{\circ} 40^{\prime} 55.3^{\prime \prime}$, W $065^{\circ} 05^{\prime} 29.7^{\prime \prime}$. Thirdly, the mapped northern margin of the Coldbrook Group north of Fundy National Park (Barr and White 2004a) is evidently not a simple contact. In outcrops along new logging roads across the contact, especially around GPS location N 45 41' 12.7”,
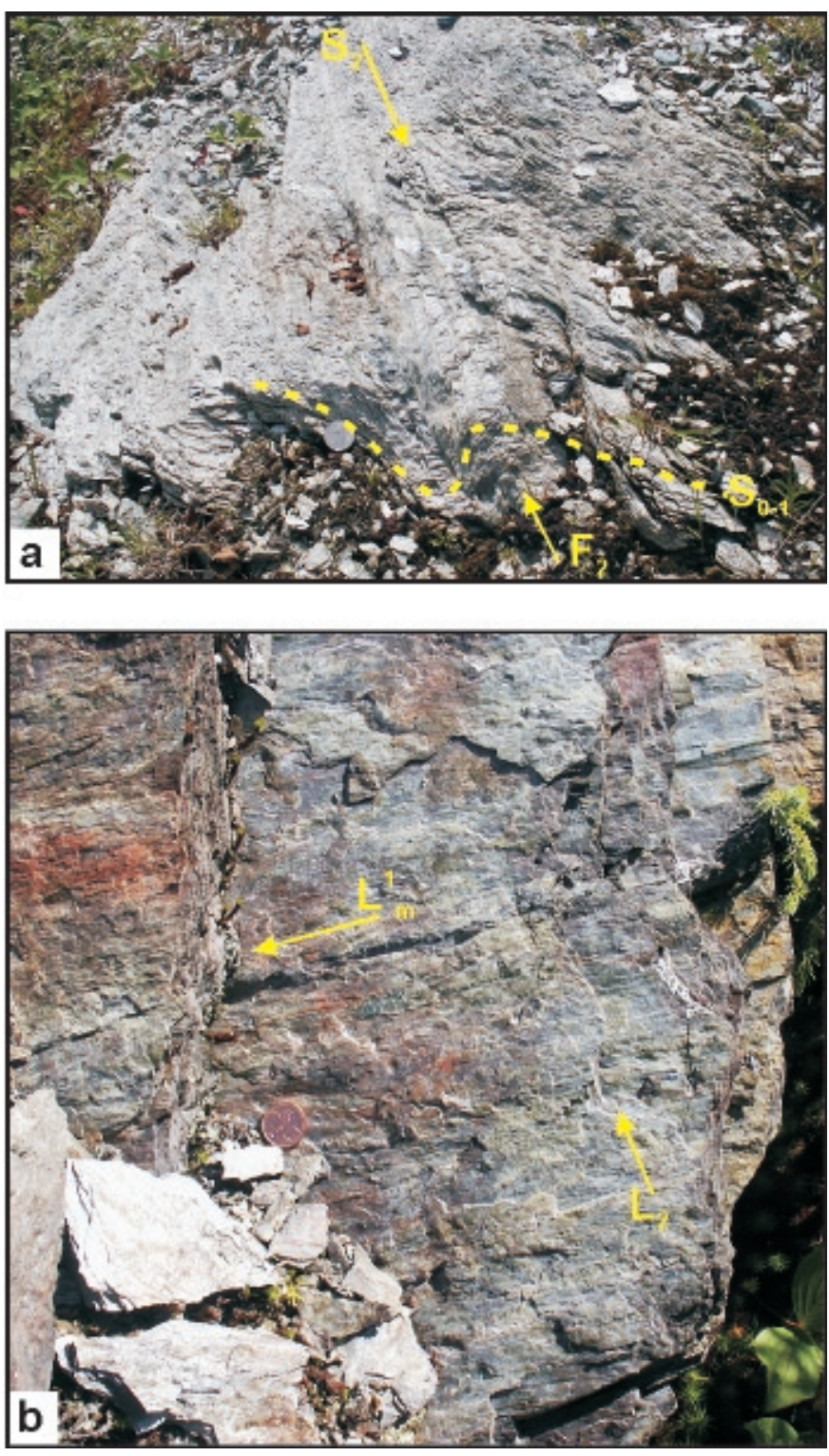

Fig. 7. Examples of $F_{2} / S_{2}$ in the Coldbrook Group. (a) Schistose felsic metavolcanic rock with $\mathrm{F}_{2}$ folds affecting the composite foliation $S_{0-1} . S_{2}$ crenulation cleavage is axial planar to $\mathrm{F}_{2}$ folds, in the Silver Hill Formation exposed on logging road north of Old Shepody Road (GPS N 45 $40^{\prime}$ $\left.16.6^{\prime \prime}, \mathrm{W} 065^{\circ} 04^{\prime} 52.6^{\prime \prime}\right)$. Scale $=$ coin $=2.4 \mathrm{~cm}$ diameter. (b) Foliated metarhyolite from the Silver Hill Formation with $S_{0-1}$ foliation surface displaying a weak $L_{2}$ crenulation lineation. Logging road south of Old Shepody Road (GPS $\left.\mathrm{N} 45^{\circ} 38^{\prime} 14.0^{\prime \prime}, \mathrm{W} 065^{\circ} 08^{\prime} 55.7^{\prime \prime}\right)$. Scale $=\operatorname{coin}=1.8 \mathrm{~cm}$ diameter.

W $065^{\circ} 05^{\prime} 52.5^{\prime \prime}$, interleaving of mafic rocks of the Hosford Brook Formation and granitoids of the Point Wolfe River Plutonic Suite is apparent. Shearing in both mafic and granitoid rocks suggests that the interleaving is tectonic. 


\section{Structures in the Point Wolfe River Plutonic Suite}

Exposure of rocks of the Point Wolfe River Plutonic Suite in the study area is sporadic, so as a result, conclusions are based on the best outcrops in the domain west of Fundy National Park, Ferndale domain, and the domain south of Prosser Brook between Hayward Pinnacle and Stuart Mountain. Granitoid rocks ranging from quartz diorite, through monzonite, granodiorite, and syenogranite dominate the outcrops, with the last two lithologies most common. Their textures range from medium-grained to coarse-grained (up to $5 \mathrm{~mm}$ ), and both non-porphryritic and porphyritic types occur. In all lithologies, fabrics range from absent to pervasive. The latter rocks include augen gneiss without mica growth and vary through a spectrum to phyllonite and thoroughly schistose or phyllitic(depending on mica grain-size in the foliation).

Earliest fabrics are generally free of white mica, or contain only minor amounts of white mica seen as beards on alkali feldspar porphyroclasts. The rock is an augen gneiss (Fig. 8a) which carries a pervasive foliation $\left(S_{1}\right)$ and typically a strong lineation defined by mica-beards or aggregates of chloritized mafic minerals (biotite and hornblende), termed $\mathrm{L}_{\mathrm{m}}$ (Fig. 8b). Superimposed on this 'anhydrous' tectonite is the growth of white mica defining a planar foliation (Fig. 8c) in which alkali feldspar is progressively reduced to smaller relict enclaves. Grain-size reduction is typically pronounced in these rocks, ultimately producing a greenish phyllitic phyllonite dominated by white mica and quartz with only isolated relics of alkali feldspar. These phyllonitic zones commonly have thicknesses measured perpendicular to foliation in the order of a few metres or less, but can be traced along strike for distances up to $2 \mathrm{~km}$, outcrop permitting. One such well-defined zone can be traced along the valley east of Ferndale village (around GPS location $\mathrm{N} 45^{\circ} 46^{\prime}$ 04.4" W $065^{\circ} 00^{\prime}$ 54.4").

Locally, these phyllonitic rocks carry a distinct crenulation cleavage with minor folds of the primary foliation (Fig. 8d). This situation causes a crenulation lineation $\left(\mathrm{L}_{\mathrm{c}}\right)$ at a high angle to $\mathrm{L}_{\mathrm{m}}$ which tends to be close to down-dip on $\mathrm{S}_{1}$ (Figs. 2,4 ). $\mathrm{L}_{\mathrm{c}}$ ranges from horizontal, to having a plunge of $20-30^{\circ}$ to the southwest (Figs 2, 4).

In the domain south of Prosser Brook a later semi-brittle deformation(s) is superimposed on $\mathrm{S}_{1}$-foliated granitoid rocks. It is restricted to outcrops along the northern margin of the Caledonia block close to the sub-Carboniferous unconformity. The foliation $\left(\mathrm{S}_{\mathrm{L}}\right)$ is quite irregular and spaced, either representing a reorientation of alkali feldspar porphyroclasts with more white mica growth, or drastic grain-size reduction producing discrete bands of protomylonite or blastomylonite anastomosing around enclaves of foliated or non-foliated granitoid rocks $\left(S_{1}\right.$ or pre- $S_{1}$ relics). A new lineation $\left(\mathrm{L}_{\mathrm{L}}\right)$ picked out by elongate feldspar or chloritized mafic mineral aggregates is also seen (Fig. 8e). The foliation $\mathrm{S}_{\mathrm{L}}$ dips steeply to the north, and the lineation plunges toward the west around $10-30^{\circ}$ (Fig. 2, 4).

Successive development of steady-state foliation in granite without hydration, followed by discrete but pervasive ductile- shear bands at the grain scale, with more or less hydration evident, is expected in syntectonic granites, where deformation begins during sub-solidus cooling and extends through subsequent retrogression (Gapais 1989). On the other hand, the occurrence of discrete shear bands anastomosing around enclaves of lower strain, with or without hydration, is more typical of the reworking of pre-tectonic crystalline basement (Gapais 1989). In this context the transition from $S_{1}$ to $F_{2}$ folding, coeval with early high-temperature relatively dry conditions, to later widespread mica development, suggests retrogression of a syntectonic pluton, and hence is similar in age to the plutons (Neoproterozoic). The later foliation $\left(S_{L}\right)$ and lineations (with

Fig. 8. (Next page) Examples of fabrics in granitoid units. (a) Augen gneiss from the deformed part of the Blueberry Hill Granite, part of the Point Wolf River Plutonic Suite, displaying pervasive shear bands defining the $S_{1}$ foliation. Cut surface of sample from Ferndale Road, near Ferndale (GPS N 45 46' 02.8", W $065^{\circ} 00^{\prime} 41.1^{\prime \prime}$ ). Scale bar $=2$ cm. (b) Foliated Blueberry Hill Granite in ditch west of Collier Road, Ferndale (GPS N $45^{\circ} 45^{\prime} 19.5^{\prime \prime}$, W $065^{\circ} 01^{\prime}$ 25.0") with down dip lineation $\mathrm{L}_{\mathrm{m}}$ on $\mathrm{S}_{1}$ foliation. Scale bar $=5 \mathrm{~cm}$. (c) Phyllonitic Blueberry Hill Granite where $\mathrm{S}_{1}$ is a white mica foliation with feldspar relics. Ditch west of Collier Road, Ferndale (GPS N $45^{\circ} 45^{\prime} 18.3^{\prime \prime}$, W $065^{\circ}$ $\left.01^{\prime} 24.3^{\prime \prime}\right)$. Scale $=$ pen $=15 \mathrm{~cm}$. (d) Phyllonitic Blueberry Hill Granite (cut slab) with $S_{1}$ white mica foliation with feldspar relics, folded by $F_{2}$ minor fold. From same location as Fig. 8c. Scale bar $=1 \mathrm{~cm}$. (e) Foliation surface $\left(\mathrm{S}_{\mathrm{L}}\right)$ in deformed granitoid (possibly part of the Kent Hills Granodiorite, one of the younger Neoproterozoic plutons), with lineation $\left(\mathrm{L}_{\mathrm{L}}\right)$, and later fractures containing pseudotachylite (unlabeled arrows indicate location and orientation of the two sets). Logging road north of Hayward Pinnacle, Prosser Brook (GPS N 45 49" 25.5", $\left.\mathrm{W} 064^{\circ} 55^{\prime} 34.0^{\prime \prime}\right)$. Scale $=$ coin $=1.8 \mathrm{~cm}$ diameter. $(\mathrm{f})$ Foliation $\left(S_{1}\right)$ surface in the Old Shepody Road Granite, part of the Point Wolfe River Plutonic Suite, with fractures containing pseudotachylite (unlabeled arrows indicate location and orientation of the most conspicuous examples). $\mathrm{S}_{1}$ is horizontal, the fractures are vertical, north is to the right. Ditch west of logging road south of the Old Shepody $\operatorname{Road}\left(G P S N 45^{\circ} 38^{\prime} 38.6^{\prime \prime}, \mathrm{W} 065^{\circ} 10^{\prime} 13.5^{\prime \prime}\right)$. Scale = coin $=1.8 \mathrm{~cm}$ diameter. (g) Blueberry Hill Granite in ditch east of Collier Road, Ferndale, with $\mathrm{S}_{1}$ foliation including transposed quartz veins $(q)$. This is cut by later brittle fractures filled with epidote \pm quartz (unlabeled arrows indicate location and orientation). GPS N $45^{\circ} 45^{\prime} 37.5^{\prime \prime}$, W $065^{\circ} 01^{\prime} 38.6^{\prime \prime}$. Scale $=$ coin $=1.8 \mathrm{~cm}$ diameter. $(\mathrm{h})$ Sample of bleached (weathered?) granite from close to the subCarboniferous unconformity with fractures and brecciation containing pseudotachylite (dark coloured). Logging road south of Stuart Mountain, Prosser Brook(GPS N $45^{\circ}$ $\left.50^{\prime} 16.2^{\prime \prime}, \mathrm{W} 064^{\circ} 52^{\prime} 13.5^{\prime \prime}\right)$. Sample is $10 \mathrm{~cm}$ wide; the vertical black line is a pen mark. 

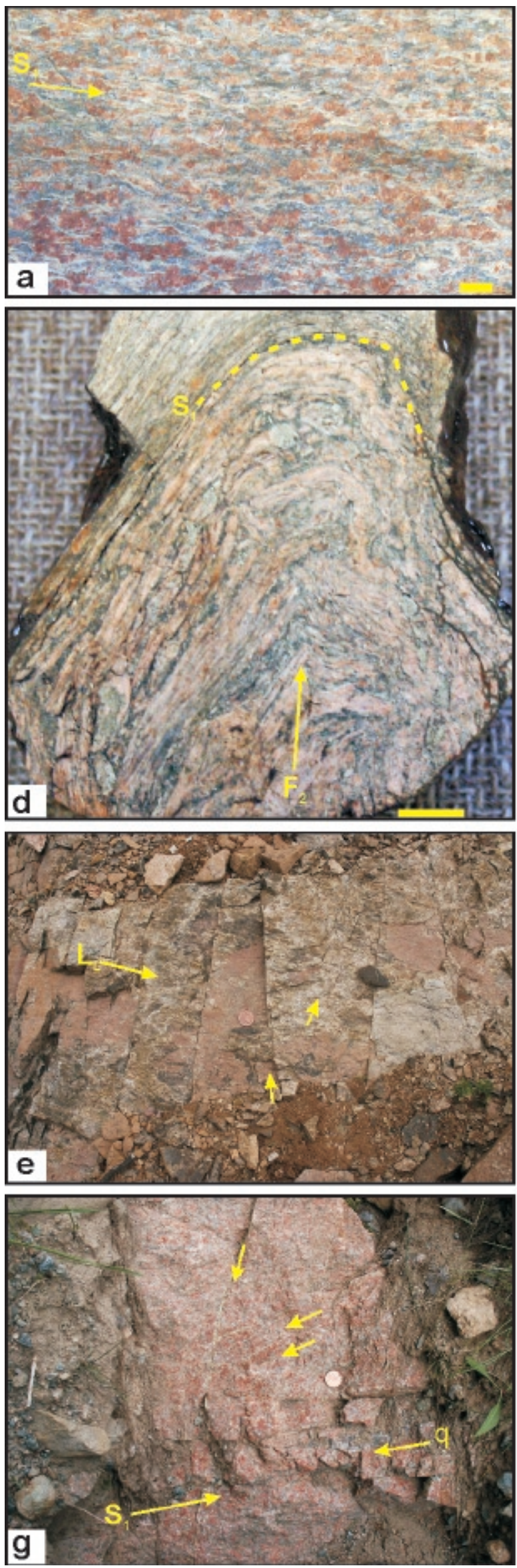
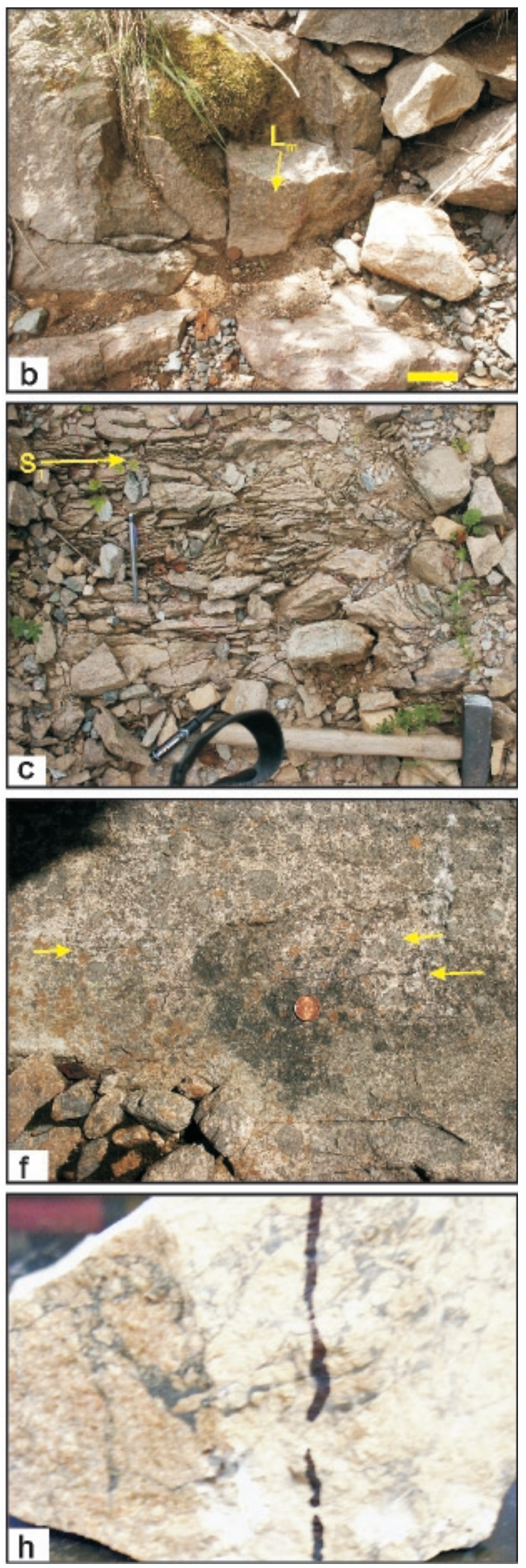
discrete mylonite, protomylonite and blastomylonite zones, and pseudotachylite-associated brecciation, Figs. 8f-h) in the domain south of Prosser Brook is more typical of reworking of considerably older and reheated crystalline rocks (Gapais 1989; Berthe et al. 1979), age of which is not yet well-constrained in the study area but could be as young as Carboniferous.

Late brittle structures have been noted west of Fundy National Park, in the Ferndale domain, and south of Prosser Brook (Fig. 8f, g, h). They are arrays of veins filled with epidote, quartz-epidote, and in places pseudotachylite. Only in the domain south of Prosser Brook have enough examples been located to make any general analysis of these features, and here some of the pseudotachylite veins form conjugate sets symmetrically disposed about the $S_{L}$ foliation. Locally the pseudotachylite veins are so abundant that they form a matrix for a breccia of $\mathrm{S}_{\mathrm{L}}$-bearing granitoid or blastomylonite.

$S_{0-1}$ in the supracrustal rocks of the Broad River and Coldbrook groups and $S_{1}$ in the granitoids appear to define a single enveloping surface, a correlation reinforced by the geometric similarities between the enclosed lineations $\mathrm{L}_{\mathrm{m}}^{1}$ and $\mathrm{L}_{\mathrm{m}}$. At the contact along the southeastern margin of the granitoid plutons, orientations seem to be continuous from granitoids into host rocks. Although the boundary is poorly exposed, north of Fundy National Park the contact zone appears to consist of alternating, interlayered enclaves of strongly foliated granitoid and supracrustal rocks with $S_{0-1} / S_{1}$ and $\mathrm{L}_{\mathrm{m}}^{1} / \mathrm{L}_{\mathrm{m}}$ constituting common fabric elements. Crenulation and folding of the phyllonitic foliated granitoids and the development of $\mathrm{F}_{2}$ folds and the $\mathrm{S}_{2}$ crenulation cleavage in the supracrustal rocks also share a common geometry, implying a correlation here too. The $S_{L}$ fabric and lineation seems to be unique to the granitoids along the northern margin in the domain south of Prosser Brook. These later brittle features with pseudotachylite are localized along the east-northeast-trending sub-Carboniferous unconformity south of Prosser Brook, and along the approximately granitoid-supracrustal contact trending north-south in the central part of the domain west of Fundy National Park; they may possibly represent faulting along these contacts.

\section{DISCUSSION AND CONCLUSIONS: A PRELIMINARY STRUCTURAL HISTORY}

With a tentative correlation between fabrics in the Broad River Group, Coldbrook Group, and the Point Wolfe River Plutonic Suite, it is possible to outline a structural history for this major high-strain zone in the Caledonian Highlands. Little of this history is calibrated as yet against a radiometric time scale; however, some conclusions can be drawn.

The earliest deformation, expressed by the ubiquitous $\mathrm{S}_{0-1} /$ $\mathrm{S}_{1}$ foliation with its related $\mathrm{L}_{\mathrm{m}}{ }_{\mathrm{m}}$ or $\mathrm{L}_{\mathrm{m}}$ mineral and stretching lineation, is found in all three units and defines an enveloping surface. Kinematic indicators are consistent in suggesting a top-to-the-southeast sense of movement along planes parallel to layering without major changes in facing or way-up. This deformation also caused local tectonic interlayering of foliated plutonic rocks and supracrustal units of the Broad River Group (and to a lesser extent, the Coldbrook Group). No major folds have been identified, and the facing and way-up data imply that these features are not present in reality, rather than not being identified as a result of poor exposure. This earliest deformation did not result in interlayering of the Broad River and Coldbrook groups to any extent. Instead, it seems to have been the result of low-angle thrusting involving mainly the Broad River Group and the Point Wolfe River Plutonic Suite, whose primary relationship has already been demonstrated to be one of host and intrusion (Barr and White 1999). The 625-615 Ma U-Pb (zircon) age of the Point Wolfe River Plutonic Suite provides a maximum age for this event. This essentially sub-horizontal tectonic regime also involved the Point Wolfe River Plutonic Suite, starting the process of uplift from hot, anhydrous conditions typified by strongly foliated S-L-tectonite augen gneiss, to higher level deformation with hydrous alteration creating mica phyllonite. Originating from a sub-solidus deformation of the Point Wolfe River Plutonic Suite, this composite fabric apparently was initiated shortly after the c. 620-615 Ma emplacement of these rocks, predating deposition of the Coldbrook Group at 560-550 Ma.

However, the early deformation continued after deposition of the Coldbrook Group because it affected those rocks, but the expression of the foliation differs considerably - primarily by degree and heterogeneity. The tectonic regime was still predominantly sub-horizontal, nevertheless, and involved some limited interfingering of Point Wolfe River plutonic tectonites with deformed units of the Coldbrook Group. Plutons intruding the Coldbrook Group have primary ages in the range 560-550 Ma, constraining deposition of the Coldbrook Group to roughly the same time interval and consistent with $\mathrm{U}-\mathrm{Pb}$ ages obtained from units in the Coldbrook Group (Barr and White 1999). This relationship suggests that the early deformation $\left(D_{1}\right)$ was a prolonged and progressive event or events, beginning prior to deposition of the Coldbrook Group (accounting for the stronger and more pervasive foliation of the Broad River Group), but continuing to affect the younger supracrustal rocks.

The high-strain zone vanishes under the Carboniferous cover in the northeast, but appears to continue to the southwest, relating to the thrusts identified around Big Salmon River on the Bay of Fundy coast to the southwest (McLeod 1987; McLeod and McCutcheon 1981; McLeod et al. 1994), and possibly continues farther west to the Saint John and Pocologan areas (Ruitenberg et al. 1973; Nance 1987; Park et al. 1994; White et al. 2006). If this correlation is valid, then a further timing constraint is evident, as the Big Salmon River structures apparently produced interlayering of the CambrianEarly Ordovician Saint John Group with the older units.

This early progressive phase of deformation appears to encompass early (pre-Coldbrook Group) stacking of Point Wolfe River plutonic rocks with rocks of the Broad River Group by thrusting, and involving excavation of plutonic rocks and their progressive hydrous alteration. This early phase ended 
with minor intercalation of the Point Wolfe River Plutonic Suite with rocks of the Coldbrook Group along thrusts of the same sense-of-shear and direction of motion, also parallel to foliation and bedding. Implicit in this interpretation is that the same structural framework incorporated the 'rifting' implied for the setting of the Coldbrook Group - possibly reactivation of older thrusts as accommodating normal faults. These same structures then reactivated as thrusts after Coldbrook Group deposition.

$\mathrm{F}_{2}$ folds and the associated $\mathrm{S}_{2}$ crenulation cleavage affected all three units: the Coldbrook Group, Broad River Group, and Point Wolfe River Plutonic Suite. Although they are upright folds, or folds very slightly overturned to the southeast, an overall asymmetry to the synformal pattern of the Coldbrook Group within the high-strain zone in the study area implies a geometric relationship and possible reactivation of the earlier structures. In the Point Wolfe River plutonic rocks, $\mathrm{F}_{2}$ folds and $S_{2}$ crenulation were imprinted on rocks that were already substantially hydrated and pervasively altered.

The first and second deformational events affected the part of the Caledonian Highlands covered by this project. Later deformational events had more restricted occurrence. For example, a zone of later high strain, superimposed on the $S_{1}$ foliation, lies along the northern contact beneath the Lower Carboniferous unconformity south of Prosser Brook. Reduction of granitoid and augen gneiss to blastomylonite or protomylonite, and breccias with or without pseudotachylite, is widespread. Likewise, pseudotachylite and brecciation are seen sporadically in the domain west of Fundy National Park, apparently related to north-south trending structures (late faults?) that cross-cut the $S_{1} / S_{0-1}$ and $S_{2}$ foliations. In the Prosser Brook - Stuart Mountain domain the spatial relationship with the fault-modified Carboniferous unconformity suggests that these features may be related to early Carboniferous deformation - thrusting related to basin inversion (Park and St. Peter 2005; Park et al. in press). At least two half-graben-related extensional episodes and two convergent basin-inversion events have been identified during Tournaisian time along this margin of the Lower Carboniferous Moncton sub-basin (Wilson 2005; Wilson and White 2006).

This study has demonstrated that the high-strain zone between Prosser Brook and the area west of Fundy National Park is evidently part of a larger set of related structures affecting all of the Caledonian Highlands. The ca. 630-620 Ma Broad River Group and associated plutons and the 560-550 Ma Coldbrook Group contain similar structural elements, as a result of a largely shared deformational history, and some of this history is apparent also in the 560-550 Ma plutonic rocks. Further studies are underway to investigate whether the history deduced in the northeastern part of the high-strain zone applies along its length, and also along apparent splays of the zone northeast of the Point Wolfe River Plutonic Suite.

\section{ACKNOWLEDGEMENTS}

Funding for the field aspects of this project was provided by a contract to Adrian Park from the Geological Surveys Branch of the New Brunswick Department of Natural Resources and a Natural Sciences and Engineering Research Council of Canada Discovery Grant to Sandra Barr. Thorough reviews by Les Fyffe and Brendan Murphy assisted in revision of this article, as did discussions with Malcolm McLeod. Adrian Park also thanks Alex Smith for field assistance.

\section{REFERENCES}

BARR, S.M., AND WhIte, C.E. 1988. Geological maps of the central Caledonian Highlands, southern New Brunswick (Parts of 21H/6, 10, 11, 14, and 15). Geological Survey of Canada Open File 1774, scale 1:50 000.

BARr, S.M., AND WhIte, C.E. 1993. Geological mapping of the eastern Caledonia Highlands, southern New Brunswick. Geological Survey Canada Open File 2600, scale 1:50 000.

Barr, S. M., AND White, C.E. 1996. Contrasts in Late Precambrian-Early Paleozoic tectonothermal history between Avalon composite terrane sensu stricto and other possible peri-Gondwanan terranes in southern New Brunswick and Cape Breton Island, Canada. In Avalonian and Related PeriGondwanan Terranes of Circum-North Atlantic. Edited by R.D. Nance and M.D. Thompson. Geological Society of America, Special Paper 304, pp. 95-108.

Barr, S. M., ANd White, C. E. 1999. Field relations, petrology and structure of Neoproterozoic rocks in the Caledonian Highlands, southern New Brunswick. Geological Survey of Canada Bulletin 530, $101 \mathrm{p}$.

BARR, S.M., AND White, C.E. (compilers) 2004a. Bedrock geology of the Caledonian Highlands of southern New Brunswick. New Brunswick Department of Natural Resources, Minerals, Policy and Planning Division, Plate 2004-138, scale 1:100 000 .

BARr, S. M. AND White, C. E. 2004b. Geology of the Quiddy River area (NTS $21 \mathrm{H} / 11 \mathrm{~b}$ ), Saint John and Kings counties, New Brunswick. New Brunswick Department of Natural Resources. Minerals, Policy and Planning Division, Plate 2004-125, scale 1:20 000.

Barr, S. M., And White, C. E. 2004c. Geology of the Mechanic Lake area (NTS $21 \mathrm{H} / 11 \mathrm{~g})$, Kings and Albert counties, New Brunswick. New Brunswick Department of Natural Resources. Minerals, Policy and Planning Division, Plate 2004-130, scale 1:20 000 .

Barr, S. M., AND White, C. E. 2004d. Geology of the Pollett River area, Albert County, New Brunswick. New Brunswick Department of Natural Resources. Minerals, Policy and Planning Division, Plate 2004-131, scale 1:20 000.

Barr, S. M., AND White, C. E. 2004e. Geology of the Kent Hills area (NTS 21 H/15d), Albert County, New Brunswick. New Brunswick Department of Natural Resources. Miner- 
als, Policy and Planning Division, Plate 2004-137, scale 1: 20000.

Barr, S. M., Bevier, M. L., White, C. E., And Doig, R. 1994. Magmatic history of the Avalon terrane of southern New Brunswick, Canada, based on U-Pb (zircon) geochronology. Journal of Geology, 102, pp. 399-409.

Berthé, D., Choukroune, P., ANd Jegouzo, P. 1979. Orthogneiss, mylonite and non-coaxial deformation of granites: the example of the South Armorican Shear Zone. Journal of Structural Geology, 1, pp. 31-42.

Bevier, M. L., AND BARR, S. M. 1990. U-Pb age constraints on the stratigraphy and tectonic history of the Avalon terrane, New Brunswick, Canada. Jounral of Geology, 98, pp. 53-63.

GapaIs, D. 1989. Shear structures within deformed granites: mechanical and thermal indicators. Geology, 17, pp. 1144-1147.

Hibbard, J.P., van Staal, C.R., Rankin, D., and Williams, H. 2006. Lithotectonic map of the Appalachian orogen (north), Canada-United States of America: Geological Survey of Canada Map 2041A, scale 1:1 500 000, 1 sheet.

McLeod, M. J. 1987. Geology, geochemistry and mineral deposits of the Big Salmon River - Goose River area, New Brunswick, Canada: Department of Natural Resources, Minerals and Energy Division, Report of Investigation 21, $47 \mathrm{p}$.

McLeod, M. J., And McCutcheon, S. R. 1981. A newly recognized sequence of possible Lower Cambrian age in southern New Brunswick: evidence for major southward directed thrusting. Canadian Journal of Earth Sciences, 18, pp. 1012-1017.

McLeod, M. J., Johnson, S. C., And Ruitenberg, A. A. 1994. Geological map of southern New Brunswick, Canada. New Brunswick Department of Natural Resources and Energy, Mineral Resources, Maps NR-5 and NR-6, scale 1:250 000 .

Murphy, J.B. 2006. Fault-controlled emplacement of arc-related magmas along the Neoproterozoic northern Gondwanan margin: an example from the Antigonish Highlands, Nova Scotia. Precambrian Research 147, pp. 306-319.

Murphy, J.B., Keppie, J.D., Stacey, J., and Trainor, R. 2001. Deciphering the Neoproterozoic history of the Hollow Fault, Avalon terrane, mainland Nova Scotia. Journal of Structural Geology, 23, pp. 1067-1077.

NANCE, R.D. 1987. Dextral transpression and late Carboniferous sedimentation in the Fundy Coastal Zone of southern New Brunswick. In Sedimentary Basins and Basin-forming Mechanisms. Edited by C. Beaumont and A.J. Tankard. Canadian Society of Petroleum Geologists Memoir 12, pp. 363-377.

Park, A. F., and St. Peter, C. J. 2005. Deformation of Lower Carboniferous rocks in the Rosevale to Saint-Joseph area (NTS $21 \mathrm{H} / 15$ ), Albert and Westmorland counties, southeastern New Brunswick. In Geological Investigations in
New Brunswick for 2004. Edited by G. L. Martin. New Brunswick Department of Natural Resources; Minerals, Policy and Planning Division, Mineral Resources Report 2005-1, pp. 25-98.

Park, A.F., Williams, P.F., Ralser, S., ANd Leger, A. 1994. Geometry and kinematics of a major crustal shear zone segment in the Appalachians of southern New Brunswick. Canadian Journal of Earth Sciences, 31, pp. 1523-1535.

Park, A. F., St. Peter, C. J., And Keighley, D. G. in press Tournaisian thrust-belt and related transpressional strikeslip zone along the southern margin of the Moncton Subbasin, southeastern New Brunswick. Bulletin, Canadian Society of Petroleum Geologists.

Ruitenberg, A. A., Venugopal, D. V., and Giles, P. S. 1973. Fundy Catalcastic Zone, New Brunswick: evidence for postAcadian penetrative deformation. Geological Society of America Bulletin, 84, pp. 3029-3044.

Ruitenberg, A. A., Giles, P. S., Venugopal, D. V., Buttimer, S. M., McCutcheon, S. R., ANd Chandra, J. 1975. Geological maps (to accompany Memoir 1) NTS $21 \mathrm{H} / 4,5 \mathrm{E}$ $\& \mathrm{~W}, 6 \mathrm{E} \& \mathrm{~W}, 10 \mathrm{~W}, 11 \mathrm{~W} \& \mathrm{~W}, 12 \mathrm{E}, 14 \mathrm{E}, 15 \mathrm{E} \& \mathrm{~W} ; 21 \mathrm{G} / 1 \mathrm{E}$ $\& \mathrm{~W}, 2 \mathrm{E}, 8 \mathrm{E} \& \mathrm{~W}$. New Brunswick Department of Natural Resources, Mineral Resources Branch, scale 1:50,000.

Ruitenberg, A. A., Giles, P. S., Venugopal, D. V., Buttimer, S. M., McCutcheon, S. R., ANd ChANDRA, J. 1979. Geology and Mineral Deposits, Caledonia area. New Brunswick Department of Natural Resources, Mineral Resources Branch, Memoir 1, $213 \mathrm{p}$.

St. Peter, C. J., Barr, S. M., ANd White, C. E. 2004. Geology of the Gowland Mountain area (NTS $21 \mathrm{H} / 14 \mathrm{a}$ ), Albert County, New Brunswick. New Brunswick Department of Natural Resources. Minerals, Policy and Planning Division, Plate 2004-133, scale 1:20 000.

White, C.E., BarR, S.M., Jamieson, R.A., And Reynolds, P.H. 2001. Neoproterozoic high-pressure/low-temperature metamorphic rocks in the Avalon terrane, southern New Brunswick, Canada. Journal of Metamorphic Geology, 19, pp. 517-528.

White, C.E., Barr, S.M., Reynolds, P.H., Grace, E., AND McMullin, D. 2006. The Pocologan Metamorphic Suite: High pressure metamorphism in a Silurian accretionary complex in the "Avalon Zone" of southern New Brunswick. The Canadian Mineralogist, 44, pp. 905-927.

Wilson, P. 2005. Stratigraphy, structural geology, and tectonic history of the McCully area, Moncton subbasin, southeastern New Brunswick. New Brunswick Department of Natural Resources. Minerals, Policy and Planning Division. Mineral Resources Report 2005-5, 104 p.

Wilson, P., AND White, J. C. 2006. Tectonic evolution of the Moncton Basin, New Brunswick, eastern Canada: new evidence from field and sub-surface data. Bulletin, Canadian Petroleum Geology, 54, pp. 319-336.

Editorial responsibility: Simon K. Haslett 